\title{
Youth entrepreneurship as a basis for sustainable urban development: social and legal aspect
}

\author{
Viktoria Lez'er ${ }^{1}$, Nina Semerianova ${ }^{2}$, Anna Kopytova ${ }^{2}$, Yuri Truntsevsky ${ }^{3}$ \\ ${ }^{1}$ Tyumen Industrial University, Volodarskogo str., 38, Tyumen, 625000, Russia \\ ${ }^{2}$ South Ural State University (National Research University), Nizhnevartovsk Branch, Mira str., 9 , \\ 628600, Russia \\ ${ }^{3}$ Ugra State University, Chekhov str., 16, Khanty-Mansiysk, 628012, Russia
}

\begin{abstract}
Young people involved in entrepreneurial activities play an important socio-economic role. This fact is recognized by the state; therefore, youth entrepreneurship is defined as one of the priority directions of youth policy in Russia. The younger generation contributes to the rapid development of small and medium-sized businesses, formation of a sustainable middle class, creation of new jobs and reduction of unemployment, which has a beneficial effect on the economy of the state as a whole. However, at present, there is a decrease in the interest of young people to participate in entrepreneurial activities, this fact has determined the relevance of the study. The purpose of the study is to analyze the problems of youth participation in entrepreneurial activities in the KhantyMansi Autonomous Area - Ugra. For successful development of youth entrepreneurship in Russia, it is necessary to conduct a single comprehensive study of this institution by the efforts of various branches of science - sociology, economics, law, etc., taking into account geographical and national characteristics of development of territories, their budgets and state of finances.
\end{abstract}

\section{Introduction}

In recent years, Russia is characterized by economic activities carried out by small and medium-sized businesses, their development contributes to reducing unemployment, filling the market with domestic goods and services, creates competitive environment, influences the gross domestic product and national budget, is a platform for forming middle class as the basis of stability of society.

In a market economy, entrepreneurship performs an economic function, manifested in the entrepreneur's desire to carry out economic activity and extract certain economic benefits, as well as acquires a social function, characterized by its individual abilities to independent activity, to overcome difficulties and achieve the goal. Special category among

${ }^{*}$ Corresponding author: a.copytowa@yandex.ru 
business entities is formed by young people, who are more willing to change, adapt to new conditions more easily and quickly, which is certainly very important for modern society.

Youth participation in entrepreneurship plays an important socio-economic role. Young people are very mobile, quickly reacting to volatility and market fluctuations, which has a positive effect on economy as a whole. In addition, employment of young people in their own business leads to creation of new jobs, reduces unemployment. Currently, the saturation of the market by graduates of vocational education system increases the risk of being unemployed. In this regard, the issue of adaptation of young people to entrepreneurial activities becomes topical, which will reduce unemployment rate and ensure possibility of self-employment, thereby ensuring formation of a generation of young entrepreneurs.

The purpose of the study is to analyze the issues of youth participation in entrepreneurial activities in the Khanty-Mansiysk Autonomous Area-Ugra.

Achievement of the goal is determined by solution of following research tasks: analysis of the regulatory framework governing youth entrepreneurship and establishing the causal relationships underlying Russian government regulation and support for entrepreneurship; determining the effectiveness of mechanisms for implementing state policy in the field of youth entrepreneurship; determining the level of interest of young people in doing business in the city of Nizhnevartovsk, identifying reasons preventing such participation.

Scientific novelty of the research consists in studying the issues of youth entrepreneurship in implementation of regional programs and effectiveness of attracting young people to participate in entrepreneurial activities in the cities of Khanty-Mansiysk Autonomous Area-Ugra.

Issues of youth entrepreneurship in the field of economics, sociology, philosophy were widely studied by foreign scientists M. Weber, K. Keynes, P. Drucker, F. Hayek. In their works entrepreneurship is considered in its natural-historical evolution. With all its general scientific value, results of these studies cannot be fully applied to the complex Russian conditions for development of market relations without taking into account peculiarities of national-historical development and socio-cultural characteristics of Russian mentality.

From the point of view of economics and political science, the issues of formation of Russian youth entrepreneurship were considered in works of L. Abalkin, E. Kapustin, V. Kasaev, and in sociological works of V. Bakshtanovsky, T. Zaslavskaya.

Studies in the field of integrating fundamentals of entrepreneurship into professional educational environment with in order to provide graduates with the opportunity to create and run their business (D.F. Barsukova, V.A. Anishchenko, V.I. Petrishche, M .V. Manova, T.N. Ivanova).

In the framework of implementation of state youth policy, an important role is assigned to the legalization of youth entrepreneurship. In development of Russian legislation on youth entrepreneurship, V.K. Andreev, I.V. Ershova, V.V. Laptev and other learned lawyers took part. However, there is no separate federal law on youth entrepreneurship yet, nor is there a formal fixation of the concept of "youth entrepreneurship" in conceptual framework of legal regulation.

Empirical basis of the study was constituted by federal laws of Russian Federation and by-laws and regulations governing relations in the field of small and medium-sized businesses, as well as the results of monitoring activities of small and medium-sized businesses in the city of Nizhnevartovsk, conducted under the municipal contract No. 1902018 of June 2018.

The main law regulating development of small and medium-sized businesses in Russia is Federal Law No. 209 dated July 24, 2007 "On Development of Small and Medium-Sized Businesses in Russian Federation", which establishes regulation at the state, regional and local levels. Because the basis for successful implementation of entrepreneurial activity can 
be made by ensuring the effective interaction of bodies of all levels of government with business entities.

According to the order of the Government of Russian Federation of November 29, 2014 N 2403-p "On approval of Fundamentals of state youth policy of Russian Federation for the period up to 2025", youth entrepreneurship is the entrepreneurial activity of citizens under the age of 30, as well as legal entities (small and medium-sized businesses), whose average age of full-time employees, as well as age of a manager, does not exceed 30 years or in whose authorized (share) capital the share of deposits of persons no older than 30 years exceeds 75 percent. The legal act establishes main tasks of state youth policy. Priority is creating conditions for development of youth entrepreneurship. Order of the Government of Russian Federation of 12.12.2015 N 2570-p "On the action plan for implementation of the Fundamentals of State Youth Policy of Russian Federation for the period until 2025" approved an action plan for implementation of fundamentals of state youth policy, in particular, clause 31 provides for development and implementation of a set of measures aimed at stimulating entrepreneurial activity in youth environment.

On the territory of Khanty-Mansiysk Autonomous Area-Ugra, state program approved by the government of Khanty-Mansi Autonomous Area-Ugra dated 09.10.2013 No. 419-p "Social and economic development, investments and innovations of the Khanty-Mansiysk Autonomous Area - Ugra for 2016-2020" is valid, according to this program the implemented activities are aimed at involving young people in entrepreneurial activities in Khanty-Mansiysk Autonomous Area - Ugra.

\section{Methods}

The following scientific methods were used in the work: dialectics, analysis, synthesis, formal legal and comparative legal method.

Theoretical aspects of the issues of legal regulation considered by such authors as V.K. Andreev, I.V. Ershov, V.V. Laptev and others allowed to comprehend legislative contradictions in regulation of relations of small and medium enterprises development. The dialectical method made it possible to comprehensively explore the essence of such contradictions. The comparative legal method made it possible to correlate federal legislation with the legislation of the region and the municipality, to reveal discrepancy and shortcomings of regulation in the field of development of small and medium-sized businesses.

\section{Results}

According to the results of monitoring of small and medium-sized businesses in the city of Nizhnevartovsk, conducted under the municipal contract No. 190-2018 dated June 29, 2018, business activities are more typical for women (56\%). Economic activity is shown by girls (women) aged from 18 to 50 years. At an older age, entrepreneurial activity decreases. Analysis of administrative, economic and other barriers that impede entrepreneurial activity in the markets of goods, works and services of the city of Nizhnevartovsk showed that there are no significant restrictions for conducting current activities or opening a new business. However, only $18.1 \%$ of respondents plan to create their own business, mostly young people aged 18 to 30 years and from 31 to 40 years. The main limiting barriers to doing business are complexity of the procedure for obtaining licenses, permits, approvals, certificates, etc., high taxes, high interest rates on loans for creation and development of businesses. 
Table 1. Do you plan to create your own business in the city of Nizhnevartovsk in the next two years?

\begin{tabular}{|c|c|c|c|c|}
\hline \multirow{2}{*}{ Answer Options } & $\begin{array}{c}\text { Number of } \\
\text { respondents }\end{array}$ & $\begin{array}{c}\text { \% of } \\
\text { respondents }\end{array}$ & $\begin{array}{c}\text { \% of the total } \\
\text { number of } \\
\text { respondents }\end{array}$ \\
\hline \multirow{2}{*}{ Valid } & Yes & 73 & 18.1 & 17.5 \\
\cline { 2 - 5 } & No & 330 & 81,9 & 79.3 \\
\hline \multicolumn{2}{|c|}{ Total answered: } & 403 & 100.0 & 96.9 \\
\hline \multicolumn{2}{|c|}{ Missed } & 13 & & 3,1 \\
\hline
\end{tabular}

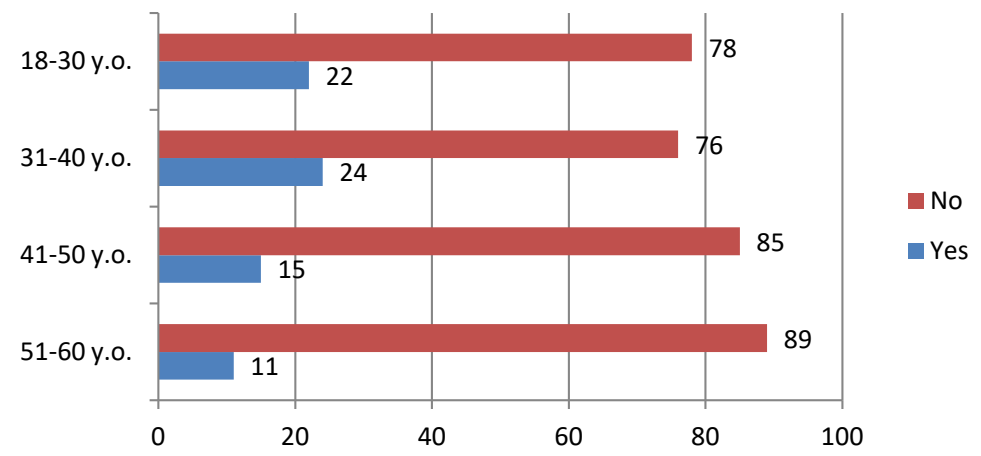

Fig.1. Consumers' interest in creating their own business in different age groups, $\%$

As a rule, young people between the ages of 18 and 30 create families, acquire housing burdened with a mortgage, and in order to get bank loans against real estate, a young family needs to have a stable job and a stable income. This situation is incompatible with the risks of entrepreneurial activity, and significantly affects decline in the number of entrepreneurs engaged in economic activities.

\section{Discussion}

Youth entrepreneurship is one of the most promising areas of development of state's economy, at the same time, it is not effectively implemented. Researchers suggest different ways of solving these problems. V.V. Sokolov focuses on the program-targeted mechanism of state support for youth entrepreneurship at the federal and regional levels. E.V. Lomteva notes the need for special work to involve young people in entrepreneurial activities. E.V. Rukina proposes creation of basic conditions for realization of entrepreneurial potential of young people, including social, as well as creation and support of activities of public associations aimed at development of socially oriented youth entrepreneurship. According to A.V. Khomutetskaya, system of regional and municipal support for youth entrepreneurship is poorly developed in Russia. Therefore, the author notes, the importance 
of comprehensive support for youth entrepreneurship was repeatedly stressed by the President, the Chairman of the Government of Russian Federation, as well as representatives of political parties and many public figures.

Thus, there is a variety of approaches to solving the problem of youth entrepreneurship. In this regard, we believe that there is a need to find a comprehensive way to reform this direction of state youth policy. The results of this study can serve as a basis for further work in the field of youth entrepreneurship, including regional ones.

\section{Conclusion}

Successful development of youth entrepreneurship is possible when favorable economic climate is established in Russia. Determining conditions of such "favorableness" is necessary conducting comprehensive study of this institution by efforts of various branches of science - sociology, economics, law and others, taking into account geographical and national peculiarities of development of territories, their budgets and state of finances.

The issue of state support for youth entrepreneurship, within the framework of new or existing programs, is important. This can be achieved by creating effective legal regulation, as well as by creating favorable financial and economic conditions that stimulate young people's interest in entrepreneurial activities. These can be programs that contain conditions for reducing or exempting from the tax burden in the first three to five years of activity, reducing the interest rate on encumbered housing, preferential financing conditions, etc.; creating conditions for law-making activities of young entrepreneurs themselves, their involvement in law-making process through participation in various meetings, commissions, etc.; creating mechanism of legal regulation on financing youth entrepreneurship, determining conditions of preferences.

\section{References}

1. M. Weber, Theory of social and economic organization, (New York, 1964)

2. J. M. Keynes, Selected Works, Trans. from ang., Preface., Comments. Comp, p. 543 (1993)

3. P. F. Drucker, Market: how to become a leader: Practice and principles, Together. Enterprise "Buck Chember International”, p. 349 (1992)

4. F. Hayek, Private Money, 118 p. (Institute of the National Model of Economics, 1996)

5. URL: http://journals.bsu.ru/content/files/articles/article_579.pdf (Last accessed: 01.27.2019)

6. http://www.dissercat.com/content/investitsionnoe-predprinimatelstvo-kak-faktorrazvitiya-zhilishchnogo-stroitelstva (Last accessed: 01.27.2019)

7. V. I. Bakshtanovsky, M. V. Sogomonov, Fair play: moral philosophy and ethics of entrepreneurship, p. 216 (Tomsk, 1992)

8. T. I. Zaslavskaya, Business layer of Russian society concept, structure, identification, Economic and social changes: monitoring public opinion, p. 7-15 (1994)

9. V. A. Anishchenko, D. F. Barsukova, Analysis of reasons constraining the development of youth entrepreneurship, Actual problems of the humanities and natural sciences, 3-7 pp. 16-19 (2016)

10. V. I. Petrishche, Innovation environment and youth entrepreneurship: problems and development prospects, Scientific-methodical electronic journal "Concept", 13, pp. 766-770 (2015) 
11. M. V. Manova, Socio-cultural aspects of the values of entrepreneurship, Azimuth of scientific research: economics and management, 4, p. 54-56 (2014)

12. T. N. Ivanova, Socio-economic aspects of entrepreneurship in the assessment of Togliatti people (empirical experience), Karelian scientific journal, 3(12), p. 56-60 (2015)

13. V. K. Andreev, Basics of entrepreneurial activity, p. 159 (Publishing House of Moscow, independent in-ta Intern. Rights, 1995)

14. I. V. Ershova, Business law: a textbook, p. 560 (Moscow, Publishing House "Jurisprudence", 2006)

15. https: // www.n-vartovsk.ru/inf/predprinimatelstvo/rmdsmsp/300246.html (Last accessed: 01.27.2019)

16. URL: https://elibrary.ru/download/elibrary_16755827_85199715.pdf (Last accessed: 01.25.2019)

17. URL: https://elibrary.ru/download/elibrary_32665892_61883981.pdf (Last accessed: 01.25.2019)

18. A. Kopytova, Procedia Engineering 165, 1132 (2016) DOI: 10.1016/j.proeng.2016.11.830

19. A. Kopytova, MATEC Web of Conferences, 106, 08056 (2017) DOI: $10.1051 /$ matecconf/201710608056

20. V. Lezier, M. Gusarova, A. Kopytova, IOP Conference Series: Earth and Environmental Science, 90(1), 012069 (2017) DOI: 10.1088/1755-1315/90/1/012069

21. N. Zotkina, M. Gusarova, A. Kopytova, Advances in Intelligent Systems and Computing, 692, 1204-1213 (2018) DOI: 10.1007/978-3-319-70987-1_129 